\title{
Equitable Compensation for Breach by FaCt-Based Fiduciaries: Tentative Thoughts on Clarifying Remedial Goals
}

\author{
JEFF BERRYMAN"
}

The Supreme Court of Canada has purported to distinguish the approach to quantifying equitable compensation from that applied to the quantification of damages in common law for breach of contract or tort. In particular. the rules associated with causation and remoteness and the application of evidential presumptions has dominated this discourse. In this comment the author suggests that these distinctions are adding to conceptual muddling of the fiduciary relationship and that it would be better for the court to embrace totally the sophisticated analytical rules of the common law rather than recreate new rules in equily. Further, he argues that the disfinctive features of the fiduciary relationship would be better recognized through the application of punitive damages rather than the distortion of compensation principles.
La Cour supreme du Canada est censée adopter des appraches distinctes selon qu'elle calcule une indemnité fondee sur l'equity ou des dommagesintéreits reconnus en common law pour violation de contrat on délit civil. Les règles associées au rapport de cause à effet et au caractère lointain du dommage, et l'application de la présomption d'èvidence régissent tout particulièrement ce discours. Selon I"auteur, ces distinctions contribuent au flou conceptuel de la relation fiduciaire; il serait pneférable que la cour s'en tienne aux règles analytiques subtiles de la common law plutól que de crèer de nouvelles règles en equity. II ajoute que les trails distinctifs de la relation fiduciaire sont mieux pris en compte par le recours aux dommages punitifs que par une distorsion des principes d'indemnisation.

\section{TABle of CONTENTS}

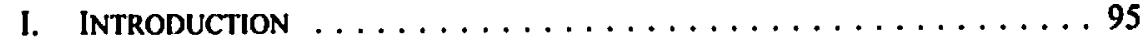

II. CAUSATION AND REMoteness $\ldots \ldots \ldots \ldots \ldots \ldots \ldots \ldots \ldots 9$

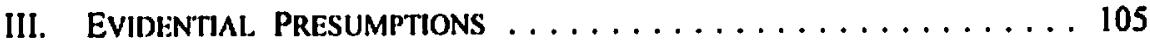

A. THE BRICKENDEN RULE $\ldots \ldots \ldots \ldots \ldots \ldots \ldots \ldots \ldots$

B. MOST FAVOURABLE USE OF

THE DisPUTEd ASSETS $\ldots \ldots \ldots \ldots \ldots \ldots \ldots \ldots \ldots$

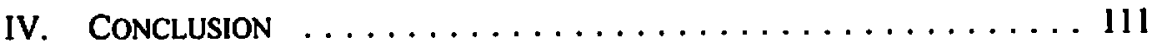

\section{INTRODUCTION}

The decisions of the Supreme Court of Canada in Guerin v. The Queen,' Canson Enterprises Lıd. v. Boughton \& $\mathrm{Co}^{2}$ and Hodgkinson v. Simms renewed interest in equitable compensation, a remedy that had, up until that time, been in a state of lethargy. Professor McCamus ${ }^{4}$ and Professor Finn ${ }^{5}$ (now a Justice of the Federal Court

Professor, Faculty of Law, University of Windsor. I am indebted to my colleagues, Professors G. Stewart and $L$. Marasinghe who provided comments on a draft of this article. All errors remain my own.

[1984] 2 S.C.R. 335 [hereinafter Guerin].

[1991] 3 S.C.R. 534 [hereinafter Canson].

[1994] 3 S.C.R. 377 [hereinafter Hodgkinson].

J. McCamus, "Prometheus Unbound: Fiduciary Obligation in the Supreme Court of Canada" (1997) 28 Can. Bus. L.J. 107.

s P. Finn, "The Fiduciary Principle" in T. Youdan, ed., Equity, Fiduciaries and Trusts (Toronto: Carswell, 1989) 1. 
of Australia) have both cautioned against the destabilizing effect that equitable compensation may have on the utility of the fiduciary principle. They are particularly concerned that because equitable compensation appears to be more generous than traditional common law assessment methods there is an incentive to litigants to pursue the former, leading to an overworking of the fiduciary concept. Viewed from Australian shores, many commentators there already assume that Canadian jurisprudence in this direction has been captured by a trend readily apparent in our southern neighbour; the use of the fiduciary principle as a device to effect a remedy rather than as a legal expression of a particular relationship. ${ }^{6}$ Both McCamus and Finn suggest that conceptual muddling of the fiduciary relationship, particularly the difficult terrain encompassed within fact-based fiduciaries, can be avoided by greater prescriptive detail in the rules of recognition of a fiduciary relationship. ${ }^{7}$ While not disagreeing with the goal, I believe that efforts in this direction are proving to be illusive. If, as suggested by Finn and McCamus, the pursuit of a fiduciary relationship is often linked to the advantages in remedial assessment principles, then an alternative approach to conceptual muddling of the fiduciary concept is to better understand these differences and why they exist. Approached from the remedial perspective we may be able to clarify the separate goals being served by impressing a relationship as being a fiduciary one, opposed to a breach of contract, or tortious duty of negligence or deceit, and thereby minimize the incentive effect equitable compensation may have.

There are essentially two positions articulated in Canada on the relationship of equitable compensation to common law damages. The McLachlin J. position, and one subscribed to by Australian and English courts, ${ }^{8}$ views equitable compensation as being quite distinct in method of assessment and quantification, extrapolating from trust principles although sometimes drawing, by analogy, support from the common law. The La Forest J. position draws a much closer analogy to the common law and will only part from the latter where there are demonstrable reasons to do so. I will suggest later that both positions are unsatisfactory. At the heart of the debate is the extent to which particular approaches to remedies should be used to reflect the more stringent standards of conduct expected of fiduciaries. Put more simply, is a purely compensatory remedy a suitable vehicle to communicate deterrence goals for fiduciaries?

The nub of this comment is that both approaches to the principles of equitable compensation assessment have corrupted the notion of compensation and in doing so fail to distinguish between compensatory and punishment or deterrence goals. The

See Meagher J.A. in the New South Wales Court of Appeal decision Breen v. Williams (1994), 35 N.S.W.L.R. 522, aff d (1995-96), 186 C.L.R. 71. And see the comments of P. Parkinson, "Fiduciary Law and Access to Medical Records: Breen v. Williams" (1995) 17 Sydney L. Rev. 433.

7 McCamus, supra note 4 at 136ff; Finn, supra note 5 at 2, and A. Mason, "The Place of Equity and Equitable Doctrines in the Contemporary Common Law World: An Australian Perspective" in D. Waters, ed., Equity. Fiduciaries and Trusts 1993 (Scarborough: Carswell, 1993) 3 at 11.

* Sec the endorsement given by the House of Lords in Target Holdings Led. v. Redferns, [1995] 3 Alt E.R. 785 [hereinafter Target Joldings], and similar sentiments expressed in a unanimous decision of the Federal Court of Australia in Commonwealth Bank of Australia v. Smith (1991), 102 A.L.R. 453, and Hill v. Rose, [1990] V.R. 129 (S.C.). 
adoption of assessment principles drawn from trust cases where the main remedial goal is either restitution or restoration does not sit comfortably with the pursuit of compensation. Without making such a distinction it is impossible for the law to rationally distinguish between the dishonest and the honest but careless fiduciary. This will become more problematic in Canada as the use of the fact-based fiduciary concept expands and where the scope of fiduciary duties encompasses more than the traditional profit and conflict rules for status-based and fact-based fiduciaries, thereby calling into demand the need for equitable compensation.

The recognizable differences between common law and equitable compensation with respect to damage quantification are: the role of causation and remoteness, whether contributory negligence or apportionment principles are applied, ${ }^{9}$ the effect of limitation periods, ${ }^{10}$ the heads of damages recoverable, ${ }^{11}$ date of damage assessment, issues of mitigation, ${ }^{12}$ the continued role of equitable presumptions, and the integration

I concede that there can be an incentive element in whether contributory negligence and apportionment principles apply to equitable compensation. The presence of contributory negligence does not operate to change the initial basis of damage assessment, only the liability of the respective parties. However, the weight of Canadian authority would see common law principles of contributory negligence and apportionment being equally applicable to equitable compensation. In Canson the majority clearly adopted the judgment of Cooke P. in Day v. Mead, [1987] 2 N.Z.L.R. 443 (C.A.) to the effect that equity would adopt, by reference, similar common law principles on apportionment and contribution.

Fiduciary claims in Canada have been advanced to gain advantage of equity's favourable limitation period. However, this advantage may have been effectively weakened in Canada by the adoption in tor law of the discoverability test for determining the point at which limitation periods start to run, see Central Trusts Co. v. Rafuse (1986), 37 C.C.L.T. 117 (S.C.C.) and M.(K.) v. M.(H.), [1992] 3 S.C.R. 6. The imposition of a limitation period is purely arbitrary but is done for the sound policy reason of wishing to draw closure of liability for a particular event. Although the existence of different limitation periods may make one form of action preferable to another they have no bearing on the principles of damage quantification adopted. Canadian courts have allowed punitive damages to accompany claims for equitable compensation. See M.(K.) v. M.(H.), ibid., and Mustaji v. Tjin (1996), 30 C.C.L.T. (2d) 53 (B.C.C.A.). Assessment date and mitigation are inextricably intertwined. It is commonly said that the date for damage assessment in equity is the date of judgment or when the restoration of the trust property should have taken place (see Re Dawson, [1966] 2 N.S.W.R. 211 (S.C.) and Target Holdings, supra note 8), but this is not a universal rule. It must be tempered by an obligation to mitigate, otherwise the person to whom the fiduciary obligation is owed could speculate at the fiduciary's expense. In Canson, MeLachlin J. suggested that the requirements of mitigation may have to be relaxed when considering equitable compensation for breach of fiduciary duty. The requirement of a plaintiff to mitigate loss is part of the law's general incentive to an individual to safeguard their own self interest. In a breach of fiduciary duty the nature of the obligation is that the fiduciary has assumed a responsibility to act in the plaintiff's best interest. It would be somewhat inconsistent to require plaintiffs who have ceded control to the fiduciary to remain eternally vigilant of their own self interest. While at some stage the plaintiffs may be expected to reassume the primary function of safeguarding their own interest, McLachlin J., at 554, indicates that this point will only arise when a plaintifr. 'after due notice and opportunity, fails to take the most obvious steps to alleviate his or her losses,' at which time we may conclude that the plaintiff is now the 'author of his own misfortune.' I would suggest that the common law principles of date regarding damage assessment and obligation to mitigate are no longer fixed and demonstrate a similar flexibility. The special concem for fiduciaries is to determine when it is reasonable to expect that they have reasserted complete self-interest over their own affairs. This is not dissimilar from the inquiry taken in many common law disputes. See for instance Asamera Oil Corp. Lid. 
of equitable discretionary maxims. Of all these differences, it has been the concern with causation and remoteness and the role of equitable presumptions that have dominated recent judicial discussion. It is also through causation and remoteness, and two particular equitable evidential presumptions (one being what is known as the Brickenden ${ }^{13}$ rule, and the other conceming the extent to which the plaintiff will be relieved of the burden of proving that he or she would have utilized the disputed resources in the most favourable fashion) ${ }^{14}$ that equity has communicated the stringency of the fiduciary relationship when compared to other similar types of contractual or tortious relationships. Simply put, if causation and remoteness principles approximate strict liability, that is a vastly more stringent form of liability than if causation accommodates elements of fault. Similarly, shifts in evidential burdens relieve a plaintiff of the onus of full proof, making his or her task that much more likely to succeed and at a higher level of compensation.

There are several remedies for breach of fiduciary duty: rescission of the agreement, constructive trust, account of profits, and equitable compensation. Until recently, the constructive trust and account of profits had been the dominant remedies. Both constructive trust and account of profits have as their main aim the disgorgement of any unauthorized profit that the fiduciary may have made from the breach of fiduciary duty. The disgorgement approach is simply based upon restitution, and its primary objective is to ensure that the fiduciary performs to an acceptable standard. Such is the stringency with which the remedy is pursued that it is often said to have a prophylactic effect, ${ }^{\text {is }}$ so that even where a principal could not have made the profit in his or her own right, the fiduciary is still required to disgorge the profit. ${ }^{16}$ However, even in these cases, the courts have displayed some sensitivity so as to distinguish between the innocent fiduciary and the one where there is a "stench of dishonesty," when making allowances for the expenses incurred by the fiduciary to make the illicit profit. ${ }^{17}$ Another rationale for such a stringent position is to relieve the plaintiff of the evidential burden of having to show that the fiduciary has acted with impropriety in a context where the fiduciary will have a superior position with regard to the facts that would prove improper dealing. ${ }^{18}$ Disgorgement remedies, because they focus on the actual gains made by the fiduciary, and are independent from any losses incurred by the person to whom the fiduciary duty is owed, are appropriate where monetary losses are less than the profits made. The constructive trust has the added advantage of being a proprietary remedy.

v. Sea Oll \& General Corporation, [1979] I S.C.R. 633, and Dodds Properties Lid. v. Canterbury Ciny Council, [1980] 1 W.L.R. 433 (C.A.).

" London Loan \& Savings Co. of Canada v. Brickenden, [1934] 2 W.W.R. 545 (P.C.) [hereinafter Brickenden].

$14 \quad$ This presumption has recently been applied in Guerin, supra note 1.

is See P. Birks, An Introduction to the Law of Restitution (New York: Oxford University, 1985) at 332.

16 See Phipps v. Boardman, [1967] 2 A.C. 46 (H.L.) and Regal (Hastings) Lid. v. Gulliver, [1967] 2 A.C. 134 (H.L.).

1) See Phipps v. Boardman, Ibid, and Warman International Lid. v. Duyer (1995), 182 C.L.R. 544 (II.C. of A.), with respect to similar principles for an account of profits.

1- See T. Youdan, “The Fiduciary Principle: Applicability of Proprietary Remedies" in Youdan, ed., supra note 5, 93, and R. Cooper \& B. Freedman, "The Fiduciary Relationship: Its Economic Character and Legal Consequences" (1991) 66 N.Y.U.L. Rev. 1045. 
However, where there is an actual monetary loss to the person to whom the fiduciary duty is owed, which is greater than the profit made by the fiduciary, a compensatory damage remedy will be preferable.

The development of equitable compensation has been the subject of extensive academic commentary, much of it critical. ${ }^{19}$ The development of equitable compensation originates with the need to find a remedy to restore the value of trust property where no unauthorized profit has been made, and no proprietary remedy would prove helpful. In particular, it has become the remedy of choice for breach of fiduciary duty by a fact-based fiduciary. ${ }^{20}$ The critical question is whether trust-like principles and equitable methods should be superimposed on the quantification of equitable compensation, or whether the developed principles of the common law should prevail.

\section{Causation and Remoteness}

It is not surprising to find that the principles associated with causation and remoteness have been the subject of divergent opinions in the Supreme Court concerning their application to equitable compensation. Similar debates have always accompanied the application of these principles wherever they have been applied. Causation satisfies the idea that a person should only be held responsible for actions over which they can effect control. As a result, liability is used as one way to correct aberrant behaviour. Proximate cause satisfies another concern, namely that it is unjust and serves no rational purpose to hold a person liable for an indeterminate amount of damage, to an indeterminate class of persons, and for an indeterminate period of time. Most contemporary thinking on both causation and remoteness sees the terrain as being heavily influenced by explicit policy arguments and that divergence from established common law doctrine should be evaluated against the policy rationale provided to justify the divergence. 21

See 1.E. Davidson, "The Equitable Remedy of Compensation" (1981-82) 13 Melb. U.L. Rev. 349; Gummow J., "Compensation for Breach of Fiduciary Duty" in Youdan, ed., supra note S, 57; L. Aitken, "Developments in Equitable Compensation: Opportunity or Danger?" (1993) 67 Aust. L.J. 596; L. Aitken, "Account or Compensation in the High Cour" (1995) 69 Aust. L.J. 782; J.D. Davies, "Equitable Compensation: 'Causation Foreseeability and Remoteness"' in Waters, ed., supra note 7, 297; C. Rickett \& T. Gardner, "Compensating for Loss in Equity: The Evolution of a Remedy" (1994) 24 Vict. U. Well. L. Rev. 19; J.D. McCamus, "Equitable Compensation and Restitutionary Remedies: Recent Developments" in Special Lecrures of the Law Society of Upper Canada 1995 (Scarborough: Carswell, 1995) 295; and J. Berryman, "Some Observations on the Application of Equitable Compensation in Western Australia: Dempster v. Mallina Holdings Lud." (1995) 25 U. West. Aust. L. Rev. 317.

Nocton v. Lord Ashburton, [1914] A.C. 932 (H.L.) is a classic example. The breach by the solicitor, in either wrongfully advising or misleading his client, Lord Ashburton, into releasing his first morigage security, advanced the solicitor's own mortgage security. Upon the mortgagor's defaulh, and Lord Ashburton's security being inadequate he successfully sued the solicitor for the injury.

21 See the comments of Sopinka J. in Snell v. Farrell, [1990] 2 S.C.R. 311 and the collection of academic commentary in E. Weinrib, ed., Tort Law (Aldershot, U.K.: Dartmouth Publishing, 1991) part III, and R. Cooke, "Remoteness of Damages and Judicial Discretion" (1978) Camb. L.J. 288. 
With respect to equitable compensation, differences of causation and remoteness principles were put into stark contrast in Canson. ${ }^{22}$ The plaintiffs, Canson, had agreed to purchase property on which it was intending to build a warehouse. The defendant, Canson's solicitor, was aware that the property had been "flipped" and that a secret profit was being made by an intermediary. The defendant did not profit from this "flip" or disclose the information to Canson. Following the purchase, Canson contracted with engineers to design and build a warehouse. Due to the negligence of the engineers, the warehouse began to sink. In an action against the engineers for negligence, the engineers were unable to pay all the damages, leaving Canson with a shortfall of $\$ 801,920$. Based on the breach of fiduciary duty, Canson commenced an action against the defendant for the outstanding amount. In the course of the trial, Canson gave evidence that they would not have proceeded with the purchase of the property if they had been informed of the "flipping" and secret profit by the vendors.

The initial starting point in any discussion of causation and remoteness is the decision in Re Dawson and the much cited dicta of Street J. that, with respect to equitable compensation, "causation, foreseeability and remoteness do not readily enter into the matter." ${ }^{23}$ Street J. applied such an approach when the particular breach of fiduciary duty concerned the activities of a trustee who was required to restore the res of the trust through equitable compensation. This approach is based on the concept of restoration, or what has the trust lost, rather than restitution, which represents the gain the trustee made from the breach. In essence, Street J.'s approach favours a "but for" test of strict causation. Applying a strict "but for" approach to Canson ${ }^{24}$ would clearly result in the solicitor being held liable for the loss. But for the solicitor's breach, the plaintiff would not have purchased the property and would not have gone ahead with the building of a warehouse and suffered damage as a result of the engineer's negligence. McLachlin J. endorsed Re Dawson ${ }^{25}$ but quickly added a limitation stating that while the assessment should be made with the full benefit of hindsight, it is "essential that the losses made good are only those which, on a common sense view of causation, were caused by the breach." ${ }^{26}$ Applying this limitation in Canson, there was no link found between the breach of fiduciary duty and the particular loss. "The solicitor's duty had come to an end and the plaintiff had reassumed control of the property."27 The approach adopted by La Forest J. (speaking for the majority) in Canson was that, where the measure of the duty is substantially the same as a common law duty then, absent different policy considerations, the result obtained in either common law or equity should be the same. Thus, doctrines of foreseeability, remoteness, and causation can be drawn by analogy into the quantification of equitable compensation.

$\begin{array}{ll}n & \text { Supra note } 2 . \\ 2 & \text { Supra note } 12 \text { at } 215 . \\ 24 & \text { Supra note } 2 . \\ 25 & \text { Supra note } 12 . \\ 26 & \text { Supra note } 2 \text { at } 556 . \\ 2 & \text { Ibid. at } 557 .\end{array}$


In Hodgkinson ${ }^{28}$ the plaintiff was a person who had recently experienced a miraculous growth in personal salary and wished to shelter as much of it as possible from tax liability. The defendant was an accountant experienced in minimizing tax, particularly through the use of multi-unit residential buildings (MURBs), devices in which the investor becomes a partner in a property development scheme. At the time the plaintiff approached the defendant for financial planning advice, the defendant was acting for Olma Brothers, a company that specialized in developing MURBs. The defendant was, in fact, instructing Olma on how to maximize the tax deductibility of the MURB schemes and had an arrangement that he would receive "extra billings" for any investors he referred to Olma. In the course of advising the plaintiff, the defendant suggested that he should invest in four of Olma's MURB schemes. The defendant did not disclose his relationship with Olma to the plaintiff. While the advice was quite sound with respect to minimizing the plaintiff's tax liability, it proved disastrous as an investment. Owing to a decline in the residential property market in Vancouver the plaintiff lost most of his investment. In a suit against the defendant, the plaintiff was successful in recovering the full value of his investment less the accrued tax advantage. ${ }^{29}$

La Forest J., speaking for the majority, held the accountant liable for breach of fiduciary duty. He applied the "but for" test. "But for" the failure of the accountant to disclose his personal dealings with the company in which he had invested the plaintiff's money, the plaintiff would not have purchased the investment, and would not have lost the value of it, albeit that the loss came as a result of the downturn in the housing market in Vancouver. The defendant, not unnaturally, raised the causation issue from Canson. In particular, he argued that even if disclosure had been made, the plaintiff would still have invested in the real estate tax shelters. This submission squarely confronted the Brickenden rule taken from the Privy Council's decision in Brickenden. $^{30}$ The effect of this rule is that where a plaintiff has made out a case of non-disclosure and has provided evidence of loss, the onus is upon the defendant to prove that the innocent party would have suffered the same loss regardless of the breach. In Brickenden, the trial judge had found that the defendant had provided no evidence to displace the plaintiff's assertion that it would not have entered into the investment if disclosure had been made.

The second causation issue raised by the defendant in Hodgkinson was whether the failure to disclose was the proximate cause of the loss, an argument that had been successful in Canson. La Forest J. distinguished Canson. In particular, in that case there "was no particular nexus between the wrong complained of and the fiduciary relationship," 31 the loss was caused by the act of a third party unrelated to the breach of fiduciary duty, and the fiduciary solicitor did not "exercise any control over the risk

Supra note 3.

See also Burns v. Kelly Peters \& Associates Lid., [1987] 6 W.W.R. I (B.C.C.A.) [hereinafter Kelly Peters] where an investment counselling business was held to a fiduciary duty to disclose conflict of interest and profit it was making on recommending the sale of certain ltawaiian condominiums as part of a balanced investment portfolio.

3) Supra note 13.

"Hodgkinson, supra note 3 at 445. 
that eventually materialized into a loss for the plaintiff." 32 In Hodgkinson the loss was directly related to the service the defendant had been retained to advise on, namely, suitable investments. The fact that a fiduciary relationship was found to exist was partially established by the fact that the defendant did exercise control over the plaintiff with respect to the types of investments and the commensurate risk he was exposed to. La Forest J. added that he did not see Canson as a retreat from the principle of full restitution. Rather, it was at one end of the spectrum at which the fiduciary had been essentially innocent, as against the other end where a fiduciary is deceitful. La Forest J. commented:

Put another way, equity is not so rigid as to be susceptible to being used as a vehicle for punishing defendants with harsh damage awards out of all proportion to their actual behaviour. On the contrary, where the common law has developed a measured and just principle in response to a particular kind of wrong, equity is flexible enough to borrow from the common law."

The defendant was held liable to make good all the losses on the investment including those attributable to the decline in market value because of an economic downturn. Also influencing La Forest J. was the simple fact that without such a remedy, persons in the position of a financial adviser would not be deterred from similar misconduct. In the language of Canson, there was now a sound policy justification - the recognition of the special relationship held by financial advisers necessitating a higher level of compensation than what would be available at common law.

McLachlin and Sopinka JJ. dissented on finding a fiduciary relationship, and simply assessed the damages based on breach of contract. The assessment in this case would result in no damages being awarded for the loss in value of the shares for three reasons. Firstly, because a simple "but for" causation test was not utilized for either equitable or common law claims. Secondly, because the losses were not caused by the defendant's breach with respect to the inadequacy of the advice, but were brought about by forces beyond his control, and were thus not within the first rule of Hadley v. Baxendale. ${ }^{34}$ And, thirdly, the losses caused by a downturn in the market were not within the reasonable contemplation of the parties as sufficiently likely to arise from the defendant's failure to disclose, and therefore, not within the second rule of Hadley v. Baxendale. ${ }^{3 s}$

The continued reliance upon a "but for" test by the majority to determine causation, although clearly rejected by the minority in Hodgkinson, should not be seen as placing principles for equitable compensation at odds with tort compensation. In Canada, tort

: $\quad$ bid.

" Supra note 3 at 444.

"1854), 9 Exch. 341.

is La lorest J. in Hodgkinson, supra note 3 at 454, does suggest that the assessment of common law damages for breach of contract in Uis case would result in a similar award to equitable compensation. This is based on the breach being a failure to provide independent advice rather than merely an obligation to disclose. This is somewhat difficult to maintain as the defendant had provided perfectly sound tax sheltering advicc. 
causation also utilizes a "but for" test for establishing "cause in fact," but this must be kept distinct from proximate cause, or "cause in law." ${ }^{16}$ Obviously there is elasticity in the notion of proximate cause, and the application of this test in negligence is different from its role in deceit. ${ }^{37}$

The method of assessment chosen by the majority in Hodgkinson is simply the application of a tort assessment for deceit. The plaintiff is being put back to the position which he or she would have been in if a fraudulent representation - here read non-disclosure - had not been made. The result is that the plaintiff is to recover all of his or her losses up to the date at which time the fraud was discovered, which in this case, did not happen until after the fall in the property market. La Forest J. draws a parallel with the decision in Burns v. Kelly Peters \& Assoc. ${ }^{38}$ In that case, the court found a defendant financial consultant guilty of actual fraud as well as in breach of fiduciary duty. The damages were based on the tortious approach to deceit. However, at that point the parallel ends. In Kelly Peters the evidence indicated that at the time of the investments in the Hawaiian condominiums, the investment consultant knew that the real estate market was depressed and that the investment was marginal. If the disclosure had been made at that stage the investors would have pulled out immediately. In Hodgkinson the advice of the defendant was sound when it was given. Had the disclosure been made at an earlier date, the plaintiff would not have incurred any loss and presumably would have kept the investment.

The question we are left with in Hodgkinson is why the defendant should be treated as being guilty of a wrong tantamount to fraud, an action that was never pleaded. The only justification is the reference to the need to deter like minded fiduciaries, particularly in the field of professional advisers. ${ }^{39}$ Damages for deceit have always had an element of punishment present, hence the comment of Lord Denning in Doyle v. Olby (Ironmongers) $\mathrm{Ltd}^{40}$ that the damages should not be limited by notions of remoteness, and that the assessment process differs from negligence. But if punishment or deterrence is the goal, it is not particularly clear why both are rigorously pursued in Hodgkinson, in the absence of any fraud or indeed negligence, and not in Canson. ${ }^{41}$ In fact, there may be even greater argument for punishment and deterrence in Canson where the breach is of a recognized fiduciary relationship by a person who is presumed

y. See L. Klar, Tort L.aw, 2d ed. (Scarborough: Carswell, 1996) at 321\%.

37 L. Klar noles that Canadian authorities are increasingly applying a reasonable foresight test and are moving away from the direct consequences test with respect to consequential losses in deceit actions: ibid. at 498.

is Supra note 29.

w La Forest J., supra note 3 at 420, 452. See also the comments of S. Waddams, "Fiduciary Duties and Equitable Compensation" (1996) 27 Can. Bus. L.J. 466.

[1969] 2 Q.B. 158 at 167 (C.A.).

1 La Forest J.'s distinction between these two cases is open to questioning. In Hodgkinson he states that in Canson there was no particular nexus between the wrong complained of and the fiduciary relationship. But it is difficult to see a particular nexus in Hodgkinson. The accountant gave good advice on the provision of tax shelters in an investment which was sound at the time the advice was given. The particular wrong, non-disclosure, had no impact on the likelihood of the market collapse. 
to know that scrupulous compliance is necessary, ${ }^{42}$ as contrasted to the situation of a fact-based fiduciary relationship in which the accountant may have unwittingly transgressed. Even if punishment or deterrence is required, vacillating between competing remedial approaches designed to attain compensation seems to be a particularly blunt weapon to achieve the result. The literature on the imposition of punitive damages in common law is rich with the type of analysis that is necessary to effect either punishment, or general and specific deterrence. ${ }^{43}$

Although I would argue La Forest J.'s position is preferable because it more closely resembles the cautious approach of common law assessment principles, it is still unsatisfactory in that it fails to give guidance on how to determine when a particular policy requires equitable compensation to move from one end of the spectrum, as in Canson, to the other end, as in Hodgkinson. The idea of this continuum is alluded to by La Forest J. in Hodgkinson where he adopts the ex curia remarks of Huband J.A. ${ }^{44}$ But whereas Huband J.A. was distinguishing between honesty and deceit, that is not the continuum presented in Hodgkinson. In tort law it is the moral culpability of the fraudulent actor that justifies the different levels of compensatory damages between deceit and negligence. But, in Hodgkinson, it is not moral culpability which justifies making the defendant the insurer of the plaintiff's losses. Rather, it is concern with the need to deter financial advisers from similar conduct. One would normally expect to find some evidential support that there was a particular problem with financial advisers before imposing extra compensatory relief. None is offered in Hodgkinson. I would argue it is better to conceptualize the policy motivation, to deter financial advisers, within the rubric of punitive damages. ${ }^{45}$

The difficulty with McLachlin J.'s approach is its more amorphous nature. McLachlin J. admits that the underlying rationale for recognizing a different approach for breach of fiduciary duty compared to negligence and contract is to give voice to the distinguishing characteristics of the former. It is noteworthy that McLachlin J. draws support from an article by R. Cooper and B. Freedman ${ }^{46}$ to illustrate these different characteristics. They distinguish between a fiduciary's duty of loyalty and his or her duty of care. Only in the former should the law infer disloyalty from its appearance and

I ann not suggesting that the solicitor in Canson should have been required to meet the damages sought by the plaintiff, but the remedy in this case, in fact, sends no signal of approbation of the solicitor's breach of fiduciary duty. Sec the Ontario Law Reform Commission's Report on Exemplary Damages (1991) for a useful survey of the justifications for imposing punitive damages.

C.R. Huband, "Remedies and Restitution for Breach of Fiduciary Duties" in The 1993 Isaac Pitblado Lectures 21 at 31 .

The Supreme Court has accepted that punitive damages can be awarded for breach of fiduciary duty, sec $M .(K)$ v. M.(H), supra note 10, and the concurring judgment of McLachlin J. in Norberg v. Wynrib, [1992] 2 S.C.R. 226. In Norberg the majority also accepted that punitive damages could be awarded where the physician's conduct was reprehensible and of a type which offended the ordinary standards of decent conduct in the community. This approach frees the awarding of punitive damages from the requirement that the defendant's conduct must be either vindictive, malicious or contumelious, the usual adjectives used to describe the type of conduct which attracts punitive damages. 
favour disgorgement remedies, whereas, in the latter, the normal rules of negligence are appropriate vehicles to communicate sufficient economic sanctions to effect deterrence and efficiency in the relationship. McLachlin J.'s approach does not seem to support the same distinction.

A second concern of McLachlin J. is that La Forest J.'s approach would create a distinction between trust and trust-like fiduciary relationships, where there is the presence of property, and to which disgorgement remedies are appropriate, and nontrust like settings, where, only common law compensatory remedies would exist. For McLachlin J. such a distinction would be artificial and undercut the obligations of trust and good faith embodied in the fiduciary relationship. I would suggest that the distinction is not artificial but is built upon the historic and special position of property in our law. The presence of property simply changes the range of remedies available. A similar issue is confronted in the intentional property torts that allow both compensatory remedies by way of damages for trespass, etc., as well as restitutionary disgorgement remedies by way of waiver of tort. This is an argument that can cut both ways, either for expansion or contraction of remedial options. With respect to the underlying nature of the fiduciary relationship, it is interesting to note that where disgorgement remedies are available in the trust setting, the law accommodates the culpability of the trustee in making allowances for the expenses incurred by the trustee acting in breach. McLachlin J.'s approach would not appear to make a similar provision with respect to equitable compensation. ${ }^{47}$

\section{Evidential Presumptions}

There have been two evidential presumptions discussed by the Supreme Court that have the potential, if applicable, to alleviate a plaintiff s burden of proof when bringing a claim for equitable compensation, and add to the putative incentives associated with a claim for equitable compensation.

\section{A. THE BRICKENDEN RULE}

The Brickenden rule has been explained by the Privy Council as follows:

When a party, holding a fiduciary nelationship, commits a breach of his duty by non-disclosure of material facts, which his constituent is entitled to know in connection with the transaction, he cannot be heard to maintain that disclosure would not have altered the decision to proceed with the transaction, because the constituent's action would be solely determined by some other factor, such as the valuation by another party of the property proposed to be mortgaged. Once the Court has determined that the non-disclosed facts were material, speculation as to what course the constituent, on disclosure, would have taken is not relevant. ${ }^{\text {ts }}$

4. McLachlin J. does make an accommodation for contributory negligence and apportionment, but that is different from the defendant's culpability. MeLachlin 3. also suggests that the approach adopted by the Supreme Court in Guerin recognized a different approach to determine equitable compensation from that applied at common law. I deal with this argument later in my comment. 
In Brickenden the defendant solicitor was found to be in breach of trust owed to the plaintiff mortgage company for failing to disclose that he was benefiting by having loans he had made to the mortgagors discharged, when, as part of a debt restructuring plan, the mortgagors were seeking to increase their indebtedness to the plaintiff. The defendant argued that the new loan, the third made to the mortgagors, would have been made regardless of his non-disclosure, simply based on the valuation of the security interest. This submission was rejected by the court as being irrelevant after the plaintiff proved that the non-disclosure related to a "material" fact.

Within Brickenden there is a contradiction. On the one hand the defendant can not "be heard," which prevents the calling of any evidence; yet on the other hand, the court, once satisfied that the non-disclosure is material, will not indulge in speculation, which invites the introduction of evidence to prove more than mere speculation. ${ }^{49}$ This point is alluded to in Commerce Capital Trust Co. v. Berk ${ }^{30}$ where Brickenden is cast as shifting the onus to the solicitor to prove that the client would have proceeded with the transaction in spite of the non-disclosure.

In Hodgkinson, La Forest J. indicated that Brickenden was not in issue because the trial judge had concluded that the defendant had not adduced any evidence to rebut the plaintiff's assertion that he would not have made the investment if disclosure had been made. As Professor Waddams has pointed out, the conclusion of La Forest J. does not quite accord with the decision of the trial judge. The trial judge had concluded that it was irrelevant what the plaintiff might have done if disclosure had been made and to consider it was inviting mere speculation. ${ }^{\text {s }}$ This finding of the trial judge accords with the strict prohibition in Brickenden. But this finding at trial is different from asserting that no evidence was adduced to rebut the plaintiff's assertion. La Forest J. went on to say, after citing Brickenden, that the principle had recently been affirmed in Rainbow Industrial Caterers Ltd. v. Canadian National Railway Co. ${ }^{32}$ In that case a negligent misrepresentation induced the plaintiff to enter into a disastrous contract. The plaintiff sought damages based on the amount needed to put it back in the position it would have been in if the representation had not been made and the contract had not been entered. The defendant argued that, even if the negligent misrepresentation had not been made, the plaintiff would have entered into an agreement with the defendant but on different terms, and therefore, the damages should be the difference between the losses on the actual contract and what would have been made on the contract that the defendant suggested the plaintiff would have entered. In rejecting the defendant's suggestion Sopinka J., for the majority, indicated that in negligent misrepresentation cases the plaintiff is entitled to the advantage of an inference that the loss flows from the defendant's misrepresentation, so that the plaintiff does not have to negate speculative hypotheses about its position if the misrepresentation had not been made.

See J. Heydon, "Causal Relationships Between a Fiduciary's Default and the Principal's Loss" (1994) 110 L.Q. Rev. 328.

(1989), 68 O.R. (2d) 257 (C.A.) at 261.

Hodgkinson v. Simms (1989), 43 B.L.R. 122 at 185 (B.C.S.C.). Waddams, supra note 39 at 468. [1991] 3 S.C.R. 3. 
The burden lies on the defendant to displace "the plaintiff's assertion of the status quo ante.".s3

The strict imperative of the Brickenden rule, ostensibly preventing the defendant from calling evidence to prove that the plaintiff would have proceeded with the transaction even if disclosure had been made, still has currency in Australia. In Maguire v. Makaronis ${ }^{54}$ the majority in the High Court of Australia commented in obiter dicla that although the application of the Brickenden rule may appear rigorous, that was not necessarily a reason to displace the rule against delinquent fiduciaries. The rigour may only be more apparent because of a tendency to readily classify as fiduciary those relationships better seen as being purely contractual or tortious. Kirby J. took a far more emphatic line on the application of the Brickenden rule. He detailed several consequences of abandoning the rule: (1) courts would have to engage in the task of unravelling multiple causes of breach; (2) it would present the risk of sanctioning a breach where the losses did not flow from the breach; (3) it would undermine the simplicity and prophylactic approach embodied in the Brickenden rule; and (4) the rule helps fulfill the purposes of equity, namely, strict loyalty and good faith to beneficiaries, dutiful enforcement of obligations, deterrence of breaches by fiduciaries, and the quick reinstatement of the beneficiary to the fullest extent possible. ${ }^{5 s}$

The Australian position accords far greater weight to the prophylactic goal of holding a fiduciary liable for breach of fiduciary duty. However, it must be appreciated that the Australian courts have adopted a more stringent approach to breach of fiduciary duty that seeks to minimize the incidence of finding fact-based fiduciary relationships or the expansion of fiduciary duties beyond a strict application of profit and conflict rules. ${ }^{36}$

The usual rationale for changes in civil evidential burdens relating to causation is to relieve the plaintiff of the burden of proving an allegation, "where the subject matter of the allegation lies particularly within the knowledge of one party," namely the defendant. ${ }^{37}$ Those circumstances are not the same as what confronts the plaintiff bringing suit for breach of a fact-based fiduciary duty and claiming equitable

5)

s4

ss

ibid. at 15-16.

(1997), 188 C.L.R. 449 (H.C. of A.).

Ibid at 492 . Although Kirby J. endorses Brickenden it is, perhaps, not in the absolute same sense that the rule has been interpreted on other occasions. Kirby J. accepts a very simple "but for" test with respect to factual causation, but then brings in the very issue which the strict application that Brickenden was designed to foreclose, namely speculation about what the plaintiff would have done had disclosure been made, into remedial selection and application. Kirby J. appears to see much more discretionary power or "clasticity" in remedial selection and commensurate orders, and that causation and fault are valid determinants when exercising this discretion.

For the Australian approach to defining fiduciary duties see the judgments of the High Court of Australia in Hospital Products Lid. v. United States Surgical Corporation (1984), I56 C.L.R. 41 and Breen v. Williams (1996), 186 C.L.R. 71. See also the scathing criticism of the Canadian approach delivered by Meagher J.A. in the New South Wales Court of Appeal decision in Breen

v. Williams (1994), 35 N.S.W.L.R. 522 at 570.

the coun, described this as one of the two principles guiding the allocation of the burden of proof in civil trials. See also J.H. Wigmore, Evidence in Trials at Common Law, 4th ed. (Boston: Little, Brown \& Co, 1981) at s. 2486. 
compensation. There is no information imbalance concerning either the cause or quantification of the plaintiff's losses. The Canadian courts have abandoned the strict application of the Brickenden rule and it now only survives as a presumption that shifts the onus upon the defendant to prove that the plaintiff would have proceeded with the impugned transaction regardless of the non-disclosure. This mirrors the position of a plaintiff bringing a deceit action or one based on negligent misrepresentation.

\section{B. MOST Favourable USE OF THE DISPUTED ASSETS}

The second evidential presumption that has been debated before the Supreme Court is the presumption that the plaintiff is entitled to have his or her damages assessed on the basis that he or she would have made the best use of the assets that are in dispute. This presumption is part of the wider notion that every presumption is made against the wrongdoer. ${ }^{58}$ The significance of this presumption was viewed by McLachlin $\mathrm{J}$. as being determinative in Guerin $^{39}$ in distinguishing between common law and equitable assessments of the recoverable damages.

In Guerin two differing damage assessments were canvassed by the court. The plaintiff Indian Band, argued that because they would never have accepted the lease of their lands to the golf course on the terms approved by the Crown, the damages should be assessed as the difference between the actual value of the lease and the value of the land as if it had been developed for long-term single dwelling leasehold lots. In this sense the plaintiff was asking for damages for their lost opportunity to develop their lands at the most remuneratively favourable form of development. In the report of the trial judge the defendant did not dispute this form of assessment but disagreed with the plaintiff's quantification of the damages. Alternatively, the defendant tried to argue that the plaintiff had experienced no loss. The latter argument was dismissed by the trial judge.

In the Supreme Court, the Crown raised the issue that the plaintiff should be confined to damages assessed on the basis of the difference in value between the actual lease and a "fair and reasonable" lease. ${ }^{60}$ This argument was rejected because the trial judge had held that the band would not have accepted a lease of the land on what would have been fair and reasonable terms for the golf club. The simple reality was that the usage of the land as a golf course was uneconomic on any terms. Wilson J. (Richie and McIntyre JJ. concurring) indicated that the assessment on the basis of loss of opportunity was appropriate because the action of breach of trust by the Crown committed the plaintiff to a lease they would never have accepted and thus deprived the Indian Band of the opportunity to realize the best value of their lands. The 
assessment date was the date of trial rather than date of breach because it was over that period that the plaintiff were deprived of realizing the potential value of their lands. ${ }^{61}$

Wilson J.'s judgment quotes extensively from Street J. in Re Dawson to the effect that the assessment in either tort or contract would be different from the law of trusts on the point of date of damage assessment. Street J.'s judgment is construed to mean that increases in market value between the date of breach and the date of recoupment of the property are ignored at common law but are taken into account in equity. ${ }^{62}$ Unfortunately, this interpretation draws too much from Street J.'s remarks. Street J. was concerned solely with the impact of currency fluctuations which at that time were ignored in common law damage assessments. In fact, it is this that largely drove the judgment in Re Dawson towards equitable compensation. This is no longer the rule and now a court in a common law action can award damages in a foreign currency or at the applicable exchange rate when the judgment is paid. ${ }^{63}$ But it is wrong to extrapolate from Street J.'s remarks a universal statement on the impact of market value differences between common law and equitable assessment dates for all forms of actions. While an action based upon breach of contract may also ignore market fluctuations after the date of breach, a similar assertion can not be made for tort actions based on conversion, detinue or trespass that have always been sensitive to market fluctuations. ${ }^{\text {of }}$

In Canson, McLachlin J. takes Wilson J.'s judgment in Guerin even further, suggesting that the case stands for the proposition that the court "rejected the submission that tort principles should govern the assessment of compensation and proceeded on the basis that the plaintiffs were entitled to compensation based on any trust principles." ${ }^{\circ s}$ And further, that the trial judge in Guerin was:

...persuaded to take an "equitable" approach based on the unforeseen escalation of the value of the land in subsequent years, and awarded $\$ 10,000,000$. In short, instead of viewing the issue of compensation from the date of the breach as required at common law, he based the damages on the trial date having regard to what actually happened, as would be the case in an equitable award for restitution.

The assertion by McLachlin J. that in Guerin the trial judge was persuaded to take into account "unforeseen" escalation in the value of land does not appear to be supported by the trial judge's findings. At the time the Crown entered into the lease of

Dickson J. (Beetz, Chouinard and Lamer JJ. concurring) simply indicated that the damages should be determined by analogy with the principles of trust law and accepted the trial judge's assessment.

Wilson J. highlights in particular the following passage from Street J.'s judgment:

Increases in market values between the date of breach and the date of recoupment are for the trustee's account; the effect of such increases would, at common law, be excluded from the computation of damages but in equily a defaulting trustee must make good the loss by restoring to the estate the assets of which he deprived it notwithstanding that market values may have increased in the meantime. Guerin, supra note 1 at 361 .

See S. Waddams, The Law of Damages, looseleaf ed. (Toronto: Canada Law Book, 1997) at s. 7.80r.

lbid. s. 1.1010 r.

Supra note 2 at 549.

Ibid. [emphasis in original]. 
the lands with the golf club the trial judge indicated, the possibility that contiguous land could be developed into long term leases for family dwellings had already been the subject of a government report and there was a great deal of public interest in developing the plaintiff's land. On the type of development that would have taken place the trial judge accepted the plaintiff's expert evidence that the plaintiffs lands would have been developed in this fashion and only disagreed on how quickly such a development would have taken place had the lease with the golf club not been negotiated. There was no finding that the increase in property values was unforeseen. ${ }^{67}$ Nor did Wilson J. in the Supreme Court comment on this aspect of the trial judge's findings.

In Guerin, Wilson J. suggests that the operation of the "most advantageous" use presumption distinguishes between common law and equitable compensation assessment principles. ${ }^{68}$ Wilson $\mathrm{J}$. suggests that in an action based on breach of contract the plaintiff Indian Band would have to prove that they intended to develop the land in a favourable fashion before being granted damages based upon that measure of assessment. In contrast, in equity, it is presumed that the plaintiffs would have developed the land in that fashion. If the above is correct then the equitable evidential presumption is of value in saving the plaintiff the trouble of establishing proof, and this would be a difference between common law and equitable compensation assessment principles.

With respect to a contract action, rarely will a plaintiff argue for loss of opportunity. As pointed out in Fuller and Perdue's celebrated article on the reliance interest in contract, $^{69}$ compensating a plaintiff's expectation interest encompasses the loss of opportunity to devote his or her resources to some alternative venture and provides the best evidence of that loss. However, if a plaintiff wishes to argue loss of opportunity he or she does carry an evidential burden to establish that loss, just as the plaintiff does to establish his or her loss of expectancy. ${ }^{30}$ With respect to tort actions of conversion and trespass, a plaintiff is entitled to damages assessed at the highest intermediate value between the time of conversion or trespass and when the plaintiff becomes aware of the tort. At that time the plaintiff is required to crystallize his or her loss and accept that the property is lost. The plaintiff cannot speculate on fluctuations in the value of the property to the risk of the defendant. This level of compensation is awarded without the need for the plaintiff to prove that he or she would have sold the property, but is granted on the basis that the defendant's actions prevented the plaintiff from having the opportunity to realize the enhanced market value. With respect to the tort actions of deceit and negligent misrepresentation, damages for lost opportunity can be pleaded as consequential losses but must be specifically proven. 
It would appear that there is no uniform common law position on the evidential requirement to prove damages for loss of opportunity and thus the presence of the presumption in an equitable action is a recognizable difference, but of what value? In Guerin the presence of the presumption only minimized the requirement that the plaintiff would have developed their lands as long term single dwelling leasehold lots. The plaintiff was still required to provide evidence quantifying the loss. The trial judge admitted that a great deal of expert testimony was given on this very point. presumption would appear to affect only a small part of the evidential burden placed upon the plaintiff to prove actual losses.

In Guerin, both the trial judge and Wilson J. adopt the general principles of damage assessment alluded to by Dickson J. in Fales v. Canada Permanent Trust $\mathrm{Co}^{72}$ and by Gordon and Culliton JJ.A. in Toronto Dominion Bank v. Uhren, ${ }^{3}$ to the effect that a beneficiary is "entitled to be placed in the same position so far as possible as if there had been no breach of trust." The The is obviously a great deal of similarity in this statement to the classic phrasing on the role of damages in tort assessment. In fact Professor Waters' commentary on these two cases, as well as McNeil v. Fultz" and MacDonald v. Hauer, ${ }^{76}$ describes a trend towards eschewing differences between trust and tort and that the "best price available" rule had been "quietly overlooked or ignored." It would appear that the judgment of Wilson J. in Guerin and McLachlin J.'s judgment in Canson are attempts to resurrect the importance of this evidential presumption as part of an effort to illustrate demarcation lines between common law and equitable compensation assessment principles.

\section{CONClusion}

Writing in Target Holdings Lid. v. Redferns, ${ }^{78}$ Lord Browne-Wilkinson prefaced his remarks on the appropriate role of equitable compensation as being conditioned by two principles.

At common law there are two principles fundamental to the award of damages. First, that the defendant's wrongful act must cause the damage complained of. Second, that the plaintiff is to be put "in the same position as he would have been in if he had not sustained the wrong for which he is now getting his compensation or reparation". Although, as will appear, in many ways equity approaches liability for making good a breach of trust from a different starting point, in my judgment those two principles are applicable as much in equity as at common law. Under both systems liability is fault based: the defendant is only liable for the consequences of the legal wrong he has done to the plaintiff

Supra note 1 at 430.

[1977] 2 S.C.R. 302 at 320, Dickson J.

(1960), 32 W.W.R. 61 at 66 (Sask. C.A.), Gordon J.A. and ibid. at 73, Culliton J.A.

Ibid. at 66.

(1906), 38 S.C.R. 198.

[1977] I W.W.R. 51 (Sask. C.A.).

Supra note 58 at 997 . Waters does go on to suggest that the presumption may still have validity and that the area provides a rich and rewarding vein to be worked in exploiting possible differences in assessments. 
and to make good the damage caused by such wrong. He is not responsible for damage not caused by his wrong or to pay by way of compensation more than the loss suffered from such wrong. The detailed rules of equity as to causation and the quantification of loss differ, at least ostensibly, from those applicable at common law. But the principles underlying both systems are the same."

Although inexplicably the House of Lords went on to endorse the remarks of McLachlin J. in Canson, there is more weight given in Lord Browne-Wilkinson's judgment to convergence of common law and equitable compensation principles than articulation of areas of divergence. The question must be asked: if the underlying principles are the same, and that through both passage of time and sheer volume of cases the common law has developed a sophisticated analytical approach to compensatory assessment, why would we wish to embark on creating a different and competing approach to compensation in equity? The only answer offered in recent judgments is the need to recognize the special status of the fiduciary relationship - to keep the fiduciary up to the mark. But this rationale has more to do with punishment and deterrence than compensation.

Where the fiduciary's breach is of a trust or trust-like context the restitutionary remedies of constructive trust and account of profits are warranted. The object of the remedy is to make the fiduciary account to the trust, or to the person to whom the fiduciary duty is owed, for the property wrongfully appropriated by the fiduciary. The remedies are restitutionary because they measure the loss by extracting the gains made by the wrongdoer. If neither restitutionary remedy is available or appropriate, as in where the fiduciary concept has been expanded to encompass fact-based relationships, or where the law holds the fiduciary in breach for acts beyond strict compliance with the duties encompassed within conflict and profit rules, then the law must pursue a different goal. It could choose punishment and deterrence, in which case the assessed damages bear little relationship to the plaintiff's losses but are related to either the incidence of offending by the particular defendant (specific deterrence) or the incidence of offending by similarly placed defendants (general deterrence), or to the amount needed to satiate the community's desire for vengeance and retribution. Alternatively, the law could pursue compensation (i.e. the actual losses experienced by the plaintiff). However, within compensation there are further choices to make. A regime which favours strict liability will make the defendant the complete insurer of the plaintiff's losses howsoever caused. The underlying rationale for this form of liability is either to maximize deterrence of particular forms of extremely dangerous wrongs or to advance distributive justice by shifting all risk to particular tortfeasors. Tort law has for the most part rejected this approach and liability is dependent upon some act of neglect and fault by the defendant which causes the plaintiff's loss, and some degree of proportionality between the tortfeasor's proven fault and the magnitude of the loss. In this way the law reinforces individual moral responsibility and advances corrective justice. Fault is found where the objective bystander could reasonably foresee that the injury caused by the tortfeasor could have been avoided through the exercise of greater care. The tortfeasor is liable only for losses that are within the proximate cause of his or her actions, because it is only over those actions that the tortfeasor exercised control. 
It would have been easy to adopt a strict liability approach to equitable compensation assessment. The judgment of Street $J$. in $R e$ Dawson launched this approach. If consistently applied the defendant solicitor in Canson should have been found liable for the full loss experienced by the plaintiff. In choosing to step back from strict liability and adopt principles of proximate cause to determine equitable compensation the Supreme Court has set in motion a clash between established common law principles derived essentially from tort law and the inchoate rules of equity derived from the Court'sown judgments in this area. At present the only ostensible reasons given for this divergence is to either keep the fiduciary "up to the mark" or to recognize particular difficulties associated with the type of relationship that financial consultants have with their clients. These reasons have little to do with compensation and more to do with punishment and selective deterrence. ${ }^{80}$

The incentive effect of equitable compensation will be much diminished if it is confined to one evidential presumption - most favourable use of disputed assets which is of little real value, rather than embracing a distinctive regime of proximate cause different from the law of torts. As Professor Birks has recently stated on the issue of causation:

The point is not that the common law's choices are above criticism or have achieved perfect stability, only that it cannot be right for une jurisdictionally determined category of the law to throw over the analysis of a difficult and recurrent problem. Or course, if both jurisdictional categories decided to take the same anti-analytical path, there would be no objection on the score of intemal contradiction within the one legal system. The objection would then be to a fundarnental change to the nature of our law, turning the courts into expensive palm trees and obliging judges to assume a kind of power which no sophisticated, plural, democratic society should ever delegate."

In Canada the experiment into expansion of fact-based fiduciary relationships and commensurate duties is not so well advanced so as to make change impossible. There is still time to abandon doctrinal distinctions between compensation in equity and in the common law, and to allow the embryonic rules of the former to be subsumed into the mature and sophisticated analysis of the latter. Up to now the policy reasons given to distinguish the fiduciary relationship appear to have more to do with punishment and deterrence than with compensation. The explicit recognition of this fact would do much to clarify remedial goals and minimize both the incentive effect and conceptual muddling of the fiduciary relationship. for the assault or breach of fiduciary duty and the need for additional punishment by way of an award of punitive damages. Sec $M .(K$.$) v. M$.(H.), supra note 10, adopting an approuch taken in 